\title{
Antibody-Induced Alterations of Thyroid Hormone Receptor during Experimental Thyroglobulin Immunization in Rabbits
}

\author{
Subhra LAhIRI, ${ }^{1, *}$ Arun Kumar Ray, ${ }^{1}$ and Alokananda ChaKraborty ${ }^{2}$ \\ ${ }^{1}$ Department of Animal Physiology and ${ }^{2}$ Department of Chemistry, \\ Bose Institute, P1/12 CIT Scheme, VII-M, Calcutta 700 054, India
}

(Received August 1, 1994)

\begin{abstract}
Summary Maximum binding capacity and dissociation constant of the triiodothyronine receptor were studied in isolated hepatic nuclei of thyroglobulin-immunized rabbits on the 98th day after the first injection. Study revealed a significant $(p<0.001)$ increase in maximum binding capacity and in dissociation constant and significantly lower $(p<0.001)$ levels of serum triiodothyronine and thyroxine. These results reflect an alteration in thyroid hormone binding capacity during experimental thyroglobulin immunization.
\end{abstract}

Key Words: $\mathrm{T}_{3}$-receptor, thyroglobulin autoimmunity, $\mathrm{T}_{3}, \mathrm{~T}_{4}$

The pathological implications of thyroid function during thyroglobulin immunization are still not clear. Changes in the $\alpha$-glycerophosphate dehydrogenase level [1], malic dehydrogenase activity [2], binding of ${ }^{125}$ I-thyroxine $\left(\mathrm{T}_{4}\right)$ with different serum protein fractions [3], alteration of serum cholesterol [4], alteration of $\mathrm{Na}^{+}, \mathrm{K}^{+}$-ATPase [5], and changes in protein and nucleic acid metabolism [6] have helped us to presume an altered thyroid status and lowered availability of thyroid hormones to the tissues, thereby disturbing the overall metabolism of the body.

Thyroid hormones have a profound effect on growth development and metabolism of all essential tissues of higher organism [7-9] and most of their physiological action is mediated via thyroid hormone receptors [10]. Abundant evidence supports the presence of an intranuclear receptor with high affinity and of a low capacity thyroid hormone binding site in rat liver, kidney, and brain [11, 12]. An increase in the number of rat brain receptors has been reported in neonatal hypothyroidism [13-15]. In human lymphocytes triiodothyronine receptors $\left(\mathrm{T}_{3}\right)$

*To whom correspondence should be addressed. 
are increased in number in hypothyroidism [16], which confirms that the changes in nuclear receptors appear to be related to the hormonal profile.

The above multiple changes during thyroglobulin immunization with altered thyroid status prompted us to study the hormone-receptor interaction for a better understanding of thyroglobulin immunity. Therefore the present investigation was aimed at evaluating the status of hepatic $T_{3}$ receptors in thyroglobulin immunized rabbits to generate a picture of receptor alterations during this condition.

\section{MATERIALS AND METHODS}

Animals. White albino rabbits (New Zealand strain) of $800-1,200 \mathrm{~g}$ obtained from LAISC, NIN, India, were used for the experiments. They were maintained at $26 \pm 1^{\circ} \mathrm{C}$ on a normal diet given ad libitum.

Immunization of rabbits. Rabbits were immunized with bovine thyroglobulin (Sigma Chemical Co., St. Louis, MO) mixed thoroughly with Freund's complete adjuvant (Diffco Laboratories, Detroit, Michigan, U.S.). Equal volumes of thyroglobulin solution $(10 \mathrm{mg} / \mathrm{ml})$ in saline and Freund's complete adjuvant were mixed thoroughly. For immunization, a volume of $0.9 \mathrm{ml}$ of the mixture was injected into each rabbit, $0.2 \mathrm{ml}$ into each footpad of the two hind legs and $0.5 \mathrm{ml}$ into the thigh muscle. One week later each animal received a second injection of $0.5 \mathrm{ml}$ of thyroglobulin-adjuvant mixture in the thigh muscle of the other hind leg, and a third injection of $0.5 \mathrm{ml}$ of mixture was made into the muscle of the originally injected leg 1 week later. Ten rabbits were immunized, and ten others served as controls that received only a saline-adjuvant mixture delivered in the same way.

Measurement of antithyroglobulin titer. Serum samples were tested for antithyroglobulin titer according to the method of Burek and Rose [17]. In brief, sheep red blood cells obtained under aseptic conditions were tanned and then coated with bovine thyroglobulin. Then the sera collected from the experimental animals were subjected to a hemagglutination technique to determine the antibody titer. All the samples were assayed in duplicate.

Assay of serum $T_{4}$ and $T_{3}$. Serum $\mathrm{T}_{4}$ and $\mathrm{T}_{3}$ concentrations were determined by use of a radioimmunoassay kit (Bhabha Atomic Research Centre, Bombay, India) having a lower limit of detectability of $0.25 \mu \mathrm{g} / \mathrm{dl}$ for $\mathrm{T}_{4}$ and of $16 \mathrm{ng} / \mathrm{ml}$ for $\mathrm{T}_{3}$. All the samples were assayed in duplicate.

Preparation of nuclei for receptor assay. The preparation of nuclei and hormone binding assay were performed according to the method of Bres and Eales [18] as modified by Dasmahapatra et al. [19]. Rabbits were sacrificed under light ether anaesthesia on the 98th day after first immunization, and the liver tissue $\left(300^{-}-400 \mathrm{mg}\right)$ was dissected out quickly. It was then blotted to remove excess blood and homogenized in $10 \mathrm{ml}$ of Buffer $\mathrm{A}\left(0.32 \mathrm{M}\right.$ sucrose, $3 \mathrm{mM} \mathrm{MgCl}_{2}, 2 \mathrm{mM} \mathrm{CaCl}_{2}$, $10 \mathrm{~mm}$ Tris- $\mathrm{HCl}$, and $5 \mathrm{~mm} \beta$-mercaptoethanol; $\mathrm{pH}$ 7.5). All these and subsequent steps were carried out at $0-4^{\circ} \mathrm{C}$. The homogenates were centrifuged at $700 \times g$ for 
Table 1. Serum $T_{4}$ and $T_{3}$ levels on the 98 th day in thyroglobulin immunize rabbits.

\begin{tabular}{lcc}
\hline Group & $\mathrm{T}_{4}(\mu \mathrm{g} / \mathrm{dl})$ & $\mathrm{T}_{3}(\mathrm{ng} / \mathrm{ml})$ \\
\hline Control & $2.70 \pm 0.01$ & $1.70 \pm 0.21$ \\
Immunized & $0.26 \pm 0.03^{*}$ & $0.17 \pm 0.09^{*}$ \\
\hline
\end{tabular}

Mean \pm SE is given. ${ }^{*} p<0.001$, vs. corresponding control value.

$10 \mathrm{~min}$. The nuclear pellets were then resuspended in $7 \mathrm{ml}$ of Buffer $\mathrm{B}(2.2 \mathrm{M}$ sucrose, $3 \mathrm{mM} \mathrm{MgCl}{ }_{2}, 2 \mathrm{mM} \mathrm{CaCl}_{2}, 10 \mathrm{mM}$ Tris- $\mathrm{HCl}$, and $5 \mathrm{~mm} \beta$-mercaptoethanol; $\mathrm{pH} 7.5$ ) and ultracentrifuged at $125,000 \times \mathrm{g}$ for $60 \mathrm{~min}$. The purified nuclear pellet was collected in $9.8 \mathrm{ml}$ of Buffer A and treated with $0.2 \mathrm{ml}$ of $5 \%$ Triton-X 100. The mixture was vortexed gently, centrifuged at $200 \times \mathrm{g}$ for $10 \mathrm{~min}$, and finally resuspended in Buffer A after three washings in the same buffer.

Assay of maximum binding capacity $(M B C)$ and dissociation constant $\left(K_{\mathrm{d}}\right)$. Six hundred fifty microliters of nuclear suspension (30-35 $\mu$ g DNA) was added to Buffer A containing ${ }^{125} \mathrm{I}_{-} \mathrm{T}_{3}(100-150 \mathrm{mCi} / \mathrm{mg}$, Bhabha Atomic Research Centre, Bombay, India) in a tracer concentration between $5 \times 10^{-11} \mathrm{M}$ to $1 \times 10^{-9} \mathrm{M}$, and the final volume was maintained at $1 \mathrm{ml}$. To determine the non-specific binding sites we ran parallel sets of tubes with $1 \times 10^{-6} \mathrm{M}$ nonradioisotopic $\mathrm{T}_{3}$. The tubes with requisite labelled hormone and nucleus were incubated for $40 \mathrm{~min}$ in a shaking water bath at $100 \times g$, transferred to ice, and left for $15 \mathrm{~min}$; and then the bound to free ratio was measured. The equilibrium dissociation constant and maximum binding capacity were determined by Scatchard plot analysis [20]. The deoxyribonucleic acid content of the nuclear pellet was measured according to the method of Burton [21].

Statistical analysis. All the statistical analysis were carried out by the modified Student's- $t$ test.

\section{RESULTS}

Table 1 reveals that by the 98th day after thyroglobulin immunization the serum $\mathrm{T}_{3}$ and $\mathrm{T}_{4}$ levels had decreased significantly $(p<0.001)$ in comparison to control values. A statistically significant increase $(p<0.001)$ in $\mathrm{MBC}$ and $K_{\mathrm{d}}$ values was observed in comparison to the control ones. The mean values for MBC and $K_{\mathrm{d}}$ obtained by Scatchard plot analysis of the control group were $1.2 \pm 0.02 \times$ $10 \mathrm{pmol} / \mathrm{ng}$ DNA and $60.5 \pm 1.1 \times 10 \mathrm{pmol} /$ liter, respectively; whereas the values for the immunized group were $1.8 \pm 0.07 \times 10 \mathrm{pmol} / \mathrm{ng} \mathrm{DNA}$ and $105.6 \pm 9.4 \times 10$ pmol/liter, respectively. The anti-thyroglobulin antibody titer showed a peak value of 1: 400,000 on the 98th day after thyroglobulin immunization; i.e., the titer was at its maximum on this day after thyroglobulin immunization.

\section{DISCUSSION}

The experimental findings indicate an increase in the maximum binding Vol. 18, No. 2, 1995 
capacity $(p<0.001)$ and in dissociation constant $(p<0.001)$ with a simultaneous increase in thyroglobulin antibody titer and a decrease in serum $\mathrm{T}_{4}$ and $\mathrm{T}_{3}$ levels on the 98th day $(p<0.001)$ after thyroglobulin immunization.

In view of the values obtained for the above parameters, it is obvious that a hypothyroidic state exists during the course of thyroglobulin immunization. This state is undoubtedly the consequence of immune complex formation, which would lead to a lowered availability of the hormone. Our previous studies also yielded the same facts [1-6]. Light microscopic observation of the thyroid gland during the course of immunization procedure revealed lymphocytic infiltration and atrophy of the thyroid follicles, which also reflects a hypothyroidic state (unpublished observations). There is also a negative correlation between $\mathrm{T}_{4}, \mathrm{~T}_{3}$ and $\mathrm{MBC}$ and $K_{\mathrm{d}}(r=-0.62$ in one tailed test). Therefore all these factors reveal a possible indication of a hypothyroidic state during conditions of thyroglobulin immunization.

The increase in maximum binding capacity and in dissociation constant is highly interesting. The higher $\mathrm{MBC}$ value might reflect an increase in hepatic nuclear receptor number, which may be due to increased synthesis or less degradation. Our results corroborate the works of other investigators [14-16]. Alteration of the $K_{\mathrm{d}}$ value is difficult to explain, and the most likely explanation may be an alteration of the receptor structure itself or a change in the factors involved in the binding process.

The data generated raise the question of the cause of the increase in hepatic $\mathrm{T}_{3}$ receptors during the condition of experimental thyroglobulin immunization when an altered thyroid status exists in the body especially in the case of the $K_{\mathrm{d}}$ value. As the cause of this increase is not known, further study is needed. India.

The work was supported by an Indian Council of Medical Research Grant, New Delhi,

\section{REFERENCES}

1. Lahiri, S., and Medda, A.K. (1992): Hepatic mitochondrial $\alpha$-glycerophosphate dehydrogenase activity in thyroglobulin immunized rabbit. Med. Sci. Res., 20, 741-742.

2. Lahiri, S., Dasmahapatra, A.K., and Medda, A.K. (1988): Hepatic cytosolic malic dehydrogenase activity in thyroglobulin immunized rabbit. Med. Sci. Res., 16, 71-72.

3. Lahiri, S., and Medda, A.K. (1986): Antithyroglobulin-thyroxine binding in thyroglobulin immunized rabbit serum. Indian J. Physiol. Allied Sci, 40, 71-76.

4. Lahiri, S., and Medda, A.K. (1987): Alteration in serum cholesterol level in thyroglobulin immunized rabbit. Indian J. Physiol. Allied Sci., 41, 129-133.

5. Habibullah, C.M., Swamy, M., and Lahiri, S. (1993): Antibody induced alterations of $\mathrm{Na}^{+}-$ $\mathrm{K}^{+}$-ATPase activity in rabbit red blood cells during thyroglobulin immunization. Methods Find. Exp. Clin. Pharmacol., 15, 455-458.

6. Lahiri, S., and Chakraborty, A. (1994): Antibody induced alterations of protein and nucleic acid metabolism during experimental thyroglobulin immunization in rabbits. Methods Find. Exp. Clin. Pharmacol., 16(8), 563-569. 
7. Oppenheimer, J.H. (1983): Molecular Basis of Thyroid Hormone, Academic Press, New York, pp. 1-60.

8. Wolf, E.C., and Wolf, J. (1964): The mechanism of action of thyroid hormone, in The Thyroid Gland, ed. by Pitt-Rivers, R., and Trotter, W.R., Butterworth, London, pp. 237260.

9. Schwatz, H.L. (1983): Effect of thyroid hormone on growth and development, in Molecular Basis of Thyroid Hormone Action, ed. by Oppenheimer, J.H., and Samuels, H.H., Academic Press, New York, pp. 413-505.

10. Hamada, S., Yoshimasa, Y., Nakamura, H., Nanno, M., and Imura, H. (1983): Regulation of nuclear thyroid hormone receptors, in Hormone Receptor and Receptor Diseases, ed. by Imura, H., and Kuzuya, H. Excerpta Medica, Amsterdam, pp. 163-170.

11. Gharbi, J., and Torresani, J. (1979): High affinity thyroxine binding to purified rat liver plasma membrane. Biochem. Biophys. Res. Commun., 88, 170-177.

12. Pliam, N.B., and Goldfine, I.D. (1977): Thyroid hormone binding sites on purified rat liver plasma membranes. Biochem. Biophys. Res. Commun., 79, 66-72.

13. Valcana, T., and Timiras, P.S. (1978): Nuclear triiodothyronine receptors in the developing rat brain. Mol. Cell. Endocrinol., 11, 31-41.

14. Ishiguro, K., Suzuki, Y., and Sato, T. (1980): Effect of neonatal hypothyroidism on maturation of nuclear triiodothyronine receptors in developing rat brain. Acta Endocrinol. (Copenhagen), 95, 495-499.

15. Lemarchand, B.T., and Berthier, C. (1981): Effect of graded dose of triiodothyronine on TSH synthesis and secretion rates in hypothyroid rats. Acta Endocrinol. (Copenhagen), 97, 74-84.

16. Liewendahl, K., Rosengard, S., and Lamberg, B.A. (1978): Nuclear binding of triiodothyronine and thyroxine in lymphocytes from subjects with hypothyroidism and resistance to thyroid hormone. Clin. Chim. Acta, 83, 41-48.

17. Burek, C.L., and Rose, N.R. (1980): Detection of antibodies, in Gradwohl's Clinical Laboratory Method and Diagnosis, ed. by Sonnenwirth, A.C., and Jarret, L., The C.V. Mosby Company, St. Louis, pp. 1257-1278.

18. Bres, O., and Eales, J.G. (1988): High affinity limited capacity triiodothyronine binding sites in nuclei from various tissues of the rainbow trout (Salmo gairdneri). Gen. Comp. Endocrinol., 69, 71-79.

19. Dasmahapatra, A.K., Ray, A.K., and Medda, A.K. (1990): In vitro demonstration of putative nuclear 3,5,3'-triiodothyronine receptors in isolated liver nuclei of Singi fish, Heteropnuestes fossilis (Bloch). Horm. Metab. Res., 22, 221-224.

20. Scatchard, G. (1949): The attraction of proteins for small molecules and ions. Ann. N.Y. Acad. Sci. U.S.A., 51, 660-672.

21. Burton, K.A. (1986): A study of the conditions and mechanism of the diphenylamine reaction for the colorimetric estimation of deoxyribonucleic acid. Biochem. J., 62, 315-323. 